\title{
THE INFLUENCE OF EMPLOYEE JOB SATISFACTION AND SERVICE QUALITY ON PROFITABILITY IN PT. BANK JATIM: CUSTOMER SATISFACTION AS THE INTERVENING VARIABLE
}

\author{
Finanda Yogi Dwi*, Lutfi \\ STIE Perbanas Surabaya, Indonesia \\ *E-mail: yogidwifinanda@gmail.com
}

\begin{abstract}
This research aimed to examine the influence of employee job satisfaction and service quality on profitability in PT. Bank Jatim, in which customer satisfaction was the intervening variable. According to literature review, the hypothesis of the research stated that employee job satisfaction and service quality influenced the profitability of the Bank and customer satisfaction as intervening variable proved to affect the relationship between independent variable and dependent variable. The data of the research were collected by using questionnaire from respondents that consisted of 92 permanent employees of PT. Bank Jatim in Gresik City. The technique of hypothesis testing was performed by using Multiple Regression Analysis (MRA) and Path Analysis using SPSS 24 statistical application. The findings of the research indicated that employee job satisfaction and service quality have positive effect to profitability and customer satisfaction was shown as intervening variable. Specifically, this research found that employee satisfaction and service quality will improve the profitability of the company.
\end{abstract}

\section{KEY WORDS}

Job satisfaction, service quality, customer satisfaction, profitability.

As time passes, business competition in Indonesia is getting tighter. It is not only in the area of commerce and industry, but the area of banking has also emerged such signs. According to the data obtained by OJK in 2017, there were 116 Banks in Indonesia. It narrows the market share in Indonesia. In Indonesia, banks can operate outside the bank's work area, thus making it less likely for other banks. Therefore, the level of inter-bank competition is getting tighter which finally can decrease bank's ability to generate profits, (Soedarmono et al., 2013).

The little opportunity is contested by the banks in Indonesia with the proposed market share that is still promising. Customers become the consumers, (Nier, 2005). The customer would want its needs to be met by the Bank, as well as from the Bank's point of view. The Bank should also pay attention to its obligations as well as the needs and desires of its customers as partners of the bank itself, so that they not move to competitor banks (Berger et al., 2009). Banks should pay close attention to the good and perfect services for the service users in the bank that ultimately affect the ability to generate profits (Beck, 2013).

For a company runs in the field of services, employees are a great asset for the company in achieving company goals (Koys, 2001). The same case happens to companies engaged in the field of banking. To achieve the goals of banking companies is by generating profit or obtaining maximum profitability. Regarding to this issue, the management surely optimize the various motivations for employees in growing their spirit to work that can ultimately improve the company's performance, (Ramlall, 2004). Chi and Gursoy (2009) stated that employee satisfaction can have a positive influence on the company's financial performance.

Behind the success of the provision of services that cause the customers satisfied, there is a big role of employees who provide these services, (Spring and Araujo, 2009). If the employee is satisfied at the workplace, the employee will serve the customer with all their hearts and full of hospitality and empathy. It is absolutely influences the service to customers. If the customers feel disappointed, they will run to another bank and then the 
image of the company will decrease and this may influence the profitability of the banking company. Naseem et al (2011) and Ariani (2015) stated that customer satisfaction can be influenced by employee satisfaction within the company; the more satisfied the employees to the rights given by the management, they will be more motivated in the giving the service to the customer so as to create customer satisfaction. Meanwhile, Tarigan and Widjaja, (2011) get the latest fact that employees are satisfied with the job and the rights given by management for themselves affect customer satisfaction because of the good service they are offered. So it can be concluded that job satisfaction from employees can affect customer satisfaction and indirectly can help to achieve the company's main goal that is the achievement of profit or profitability.

\section{METHODS OF RESEARCH}

Based on the scope of the research, this research can be categorized as explanative research because this research correlates between cause and effect that occur between the variables under research (Sujoko Efferin, 2004). Data collection was only conducted once after distributing the questionnaires to the employees of PT. Bank Jatim Branch Gresik.

The population of this research is all permanent employees of PT. Bank Jatim all over East Java branches, Batam Branches and Jakarta Branches which amounted to 4045 branches. The sample of this research is all permanent employees of PT. Bank Jatim Branch Gresik which amounted to 92 people. Questionnaires were distributed to all employees of PT. Bank Jatim Gresik consisting of Branch Manager, Head of Operations, Branch Head, Supervisor, Staff, Apprenticeship Staff and Security.

Table 1 - Respondent Profiles

\begin{tabular}{|c|c|c|c|}
\hline Respondent Profiles & Category & Frequency & Percentage \\
\hline \multirow{3}{*}{ Sex } & Male & 56 & $60.9 \%$ \\
\hline & Female & 36 & $39.1 \%$ \\
\hline & Total & 92 & $100 \%$ \\
\hline \multirow{5}{*}{ Age } & $20-30$ & 48 & $52.5 \%$ \\
\hline & $31-40$ & 27 & $29.3 \%$ \\
\hline & $41-50$ & 10 & $10.9 \%$ \\
\hline & $51-58$ & 7 & $7.6 \%$ \\
\hline & Total & 92 & $100 \%$ \\
\hline \multirow{5}{*}{ Division/Unit } & Customer Service & 33 & $35.9 \%$ \\
\hline & Credit & 35 & $38 \%$ \\
\hline & Accounting, Marketing etc. & 17 & $18.5 \%$ \\
\hline & Branch Management & 7 & $7.6 \%$ \\
\hline & Total & 92 & $100 \%$ \\
\hline \multirow{8}{*}{ Position } & Branch Manager & 1 & $1.1 \%$ \\
\hline & Head of Operations and the same level & 6 & $7.6 \%$ \\
\hline & Supervisor and the same level & 18 & $19.6 \%$ \\
\hline & Staff & 59 & $64.1 \%$ \\
\hline & Security & 4 & $4.3 \%$ \\
\hline & Driver & 3 & $3.3 \%$ \\
\hline & Apprenticeship Staff & 1 & $1.1 \%$ \\
\hline & Total & 92 & $100 \%$ \\
\hline
\end{tabular}

Based on the results of data collection that had been conducted before, the data of respondent identity were obtained to complete the research information. The data of respondent identity were identified by sex, age, division or unit, and job position. Based on sex profile, the respondents were dominated by 56 male respondents or $60.9 \%$ and 36 female respondents or $39.1 \%$. Based on age profile, the respondents were dominated by 48 respondents aged $20-30$ years or $52.5 \%, 27$ respondents aged $32-40$ years or $29.3 \%, 10$ respondents aged $41-50$ years or $10.9 \%$ and only 7 respondents aged $51-58$ years or $7.6 \%$.

Based on division profile, the division of credit was dominated by 35 respondents or $38 \%$. The second place was customer service with 33 respondents or $35.9 \%$. Accounting, marketing \& others with 17 respondents or $18.5 \%$, and branch management was only 7 
respondents or $7.6 \%$ from $100 \%$. Based on position profile, respondents were dominated by staff with $64.1 \%$ or 59 respondents, by supervisors and the same level with 18 respondents or $19.6 \%$, by head of operations and the same level with 6 respondents or $7.6 \%$, by security guard with 4 respondents or $4.3 \%$, by driver with 3 respondents or $3.3 \%$, and by branch manager and apprenticeship staff with only 1 respondent from each division or $1.1 \%$.

\section{RESULTS OF STUDY}

Validity Test. The first evaluation of the measurement model is the validity test. To see the result of validity test, it is conducted by looking at the result of measurement instrument (questionnaire) on SPSS output by using bivariate correlation with sig < 0.05 (Imam Gozali, 2011). The results of the validity test can be seen in the following table:

Table 2 - The Result of Validity Test

\begin{tabular}{|c|c|c|c|}
\hline Variable & Indicator & p-value & Sig \\
\hline & EJS 1 & 0.445 & 0.000 \\
\cline { 2 - 4 } & EJS 2 & 0.249 & 0.017 \\
\cline { 2 - 4 } EMPLOYEE JOB SATISFACTION $\left(\mathrm{X}_{1}\right)$ & EJS 3 & 0.751 & 0.000 \\
\hline \multirow{3}{*}{ SERVICE QUALITY $\left(\mathrm{X}_{2}\right)$} & SQ 1 & 0.738 & 0.000 \\
\cline { 2 - 4 } & SQ 2 & 0.510 & 0.001 \\
\cline { 2 - 4 } & SQ 3 & 0.328 & 0.000 \\
\cline { 2 - 4 } & SQ 4 & 0.517 & 0.000 \\
\cline { 2 - 4 } & SQ 5 & 0.809 & 0.000 \\
\hline \multirow{3}{*}{ CUSTOMER SATISFACTION $(Y)$} & CS 1 & 0.972 & 0.000 \\
\cline { 2 - 4 } & CS 2 & 0.902 & 0.000 \\
\cline { 2 - 4 } & CS 3 & 0.864 & 0.000 \\
\cline { 2 - 4 } & CS 4 & 0.830 & 0.000 \\
\cline { 2 - 4 } & CS 5 & 0.835 & 0.000 \\
\cline { 2 - 4 } & CS 6 & 0.947 & 0.000 \\
\hline \multirow{2}{*}{ PROFITABILITY (Z) } & PR 1 & 0.894 & 0.000 \\
\cline { 2 - 4 } & PR 2 & 0.831 & 0.000 \\
\hline & PR 3 & 0.950 & 0.000 \\
\hline
\end{tabular}

The result of validity test can be seen in this table that we can see all valid variables because sig $<0.05$. Reliability test is the second evaluation of the measurement model. To see the results of reliability test, it is conducted by looking at the results of measurement instrument (questionnaire) on SPSS output using cronbach alpha with sig > 0.06 (Imam Gozali, 2011). The result of reliability test can be seen in the following table:

Table 3 - The Result of Reliability Test

\begin{tabular}{|c|c|}
\hline Variable & Cronbach Alpha \\
\hline Employee Job Satisfaction & 0,685 \\
\hline Service Quality & 0,836 \\
\hline Customer Satisfaction & 0,980 \\
\hline Profitability & 0,950 \\
\hline
\end{tabular}

The result of reliability test can be seen in the following table, we can see all the reliable variables, because sig $>0.06$. After obtaining the results of validity and reliability test, we can continue the third evaluation from measurement model that is Multiple Regression Analysis. This evaluation can show the influence of Independent Variable $X_{1}$ (Employee Satisfaction) and Independent Variable $X_{2}$ (Service Quality) to Dependent Variable Z (Profitability). The results of Multiple Regression Analysis can be seen in table 4.

In this table, it can be seen that there is influence of independent variable (employee job satisfaction and service quality) to dependent variable (profitability). This conceptual model can explain that the contribution percentage of independent variable to dependent variable was $75.3 \%$, while the rest was $24.7 \%$. It was influenced by other variables that were not included in this research model. 
Table 4 - The Result of Multiple Linear Regression Output (Coefficient of Determination) Summary Model

\begin{tabular}{|c|c|c|c|c|}
\hline Model & $\mathrm{R}$ & $\mathrm{R}$ Square & Adjusted R Square & Std. Error of the Estimate \\
\hline 1 & $.868^{\mathrm{a}}$ & .753 & .747 & .57304 \\
\hline \multicolumn{2}{|l}{ a. Predictors: (Constant), SQ, EJS }
\end{tabular}

Table 5 - The Results of Multiple Linear Regression Output (t-Test)

\begin{tabular}{|c|c|c|c|c|c|c|}
\hline \multicolumn{7}{|c|}{ Coefficients $^{a}$} \\
\hline \multirow{2}{*}{\multicolumn{2}{|c|}{ Model }} & \multicolumn{2}{|c|}{ Unstandardized Coefficients } & \multirow{3}{*}{$\begin{array}{c}\text { Standardized Coefficients } \\
\text { Beta } \\
\end{array}$} & \multirow{3}{*}{$\frac{t}{-1.112}$} & \multirow{3}{*}{$\begin{array}{l}\text { Sig. } \\
.269\end{array}$} \\
\hline & & $\mathrm{B}$ & Std. Error & & & \\
\hline \multirow{3}{*}{1} & (Constant) & -.266 & .239 & & & \\
\hline & EJS & .656 & .072 & .546 & 9.051 & .000 \\
\hline & $S Q$ & .554 & .073 & .459 & 7.618 & .000 \\
\hline
\end{tabular}

Based on the table, it can be seen that the independent variable $X_{1}$ (Employee Job Satisfaction) is positively associated with the dependent variable $Z$ (Profitability) because the sig value of the independent variable $X_{1}$ (Employee Job Satisfaction) is 0.000 in which it is less than $<0.05$. The independent variable $X_{2}$ (Quality of Service) is positively related to the dependent variable $Z$ (Profitability) because sig value of independent variable $X 2$ (Service Quality) is 0.000 in which it is less than $<0.05$. The results showed that all independent variables influenced the dependent variable. To prove customer satisfaction as the intervening variable, we can use path analysis with SPSS 24 software. The results of path analysis are shown in the following table:

Table 6 - The Results of Multiple Linear Regression Output (Path Analysis)

\begin{tabular}{|c|c|c|c|c|c|c|}
\hline \multicolumn{7}{|c|}{ Coefficients $^{a}$} \\
\hline & \multirow{2}{*}{ Model } & \multicolumn{2}{|c|}{ Unstandardized Coefficients } & \multirow{2}{*}{$\begin{array}{c}\frac{\text { Standardized Coefficients }}{\text { Beta }} \\
\end{array}$} & \multirow{2}{*}{$\mathrm{T}$} & \multirow{2}{*}{ Sig. } \\
\hline & & B & Std. Error & & & \\
\hline \multirow{4}{*}{1} & (Constant) & -.242 & .150 & & -1.611 & .111 \\
\hline & EJS & .206 & .060 & .171 & 3.450 & .001 \\
\hline & SQ & .234 & .053 & .194 & 4.399 & .000 \\
\hline & CS & .698 & .060 & .677 & 11.717 & .000 \\
\hline
\end{tabular}

\section{DISCUSSION OF RESULTS}

Employee Job Satisfaction $\left(X_{1}\right) \rightarrow$ Customer Satisfaction $(Y) \rightarrow$ Profitability $(Z)$. From the results of Path Analysis we know that there was a direct relationship between the independent variable $X_{1}$ (Employee Job Satisfaction) $\rightarrow Z$ (Profitability) amounted to 0.171 . Indirect relationship between $\mathrm{X}_{1}$ (Employee Job Satisfaction) $\rightarrow \mathrm{Y}$ (Customer Satisfaction) $\rightarrow$ $Z$ (Profitability) was $0.171 \times 0.677=0.369$. Therefore, the total relationship between independent variable to dependent variable was $0.171+0.369=0.54$. It meant that customer satisfaction that was assumed as intervening variable can be proven as true intervening variable because the total value of indirect relationship from independent variable $\left(X_{1}\right)$ through the intervening variable $(Y)$ then to dependent variable $(Z)$ was 0.369 ; bigger than direct relationship from independent variable $\left(X_{1}\right)$ directly to dependent variable $(Z)$ that was amounted to 0.171 .

Service Quality $\left(X_{2}\right) \rightarrow$ Customer Satisfaction $(Y) \rightarrow$ Profitability $(Z)$. From the results of Path Analysis we know that there was a direct relationship between the independent variable $X_{2}$ (Service Quality) $\rightarrow Z$ (Profitability) amounted to 0.194 . Indirect relationship between $X_{2}$ (Service Quality) $\rightarrow Y$ (Customer Satisfaction) $\rightarrow Z$ (Profitability) was $0.459 \times 0.677=0.311$. Therefore, the total relationship between independent variable to dependent variable was $0.195+0.311=0.505$. It meant that customer satisfaction that was assumed as intervening variable can be proven as true intervening variable because the total value of indirect relationship from independent variable $\left(\mathrm{X}_{2}\right)$ through the intervening variable $(\mathrm{Y})$ then to 
dependent variable $(Z)$ was 0.311 ; bigger than direct relationship from independent variable $\left(X_{2}\right)$ directly to dependent variable $(Z)$ that was amounted to 0.195 .

\section{CONCLUSION AND SUGGESTIONS}

Based on the findings and discussion of the research that had been described, it can be concluded that employee job satisfaction and service quality positively affect the profitability of the Bank but there is a finding that customer satisfaction can increase the influence of job satisfaction and employee service quality to the profitability of the Bank. Based on these findings, it is suggested that further researchers develop this research by examining other factors that may influence profitability. Moreover, the addition of the number of samples is also needed to be taken into account considering the large number of respondents and other companies. Future researchers may consider other methods to examine employee job satisfaction, for example by using in-depth interviews to the employees, so that the information can be more varied than using questionnaire as the research instrument in which the answers are available on the sheets.

\section{REFERENCES}

1. Chi, C.G. \& Gursoy, D. (2009). "Employee Satisfaction, Customer Satisfaction, and Financial Performance: An empirical examination". International Journal of Hospitality Management, Vol. 28, No. 2, pp. 245-253

2. Tarigan, J., \& Widjaja, D. C. (2011). The Impact of Employee Satisfaction on Profitability of Restaurants And CafÃ $\odot$ s: A Research in Surabaya, Indonesia (Doctoral dissertation, Petra Christian University).

3. Ariani, D. W. (2015). Employee Satisfaction and Service Quality: Is There Relations?. International journal of business research and management, 6(3), 33-44.

4. Naseem, A., Sheikh, S. E., \& Malik, K. P. (2011). "Impact of Employee Satisfaction on Success of Organization: Relation Customer Experience and Employee Satisfaction". International Journal of Multidisiplinary Sciences and Engineering, Vol 2, No 5. pp. 41 46.

5. Soedarmono, W., Machrouh, F., \& Tarazi, A. (2013). Bank competition, crisis and risk taking: Evidence from emerging markets in Asia. Journal of International Financial Markets, Institutions and Money, 23, 196-221.

6. Nier, E. W. (2005). Bank stability and transparency. Journal of Financial Stability, 1(3), 342-354.

7. Berger, A. N., Klapper, L. F., \& Turk-Ariss, R. (2009). Bank competition and financial stability. Journal of Financial Services Research, 35(2), 99-118.

8. Beck, T., De Jonghe, O., \& Schepens, G. (2013). Bank competition and stability: crosscountry heterogeneity. Journal of financial Intermediation, 22(2), 218-244.

9. Koys, D. J. (2001). The effects of employee satisfaction, organizational citizenship behavior, and turnover on organizational effectiveness: A unit-level, longitudinal study. Personnel psychology, 54(1), 101-114.

10. Ramlall, S. (2004). A review of employee motivation theories and their implications for employee retention within organizations. Journal of American Academy of Business, 5(1/2), 52-63.

11. Spring, M., \& Araujo, L. (2009). Service, services and products: rethinking operations strategy. International Journal of Operations \& Production Management, 29(5), 444-467.

12. Schwepker Jr, C. H. (2001). Ethical climate's relationship to job satisfaction, organizational commitment, and turnover intention in the salesforce. Journal of business research, 54(1), 39-52. 